\title{
ANALYSIS OF THE FINANCIAL MANAGEMENT AND LITERATION INFLUENCE ON THE FAMILY WELFARE LEVEL (CASE STUDY ON MUSLIMAH WITH TEACHER'S PROFESSION IN SELONG DISTRICT)
}

\author{
Diah Zikrina Mulyarti \\ Tazkia Islamic University College \\ Email: diahzm@gmail.com \\ Yaser Taufik Syamlan \\ Tazkia Islamic University College \\ Email: yasersyamlan@tazkia.ac.id
}

\begin{abstract}
The purpose of this research is to determine wether the financial management variable and financial literacy affect family welfare of muslimah teachers at Selong. 221 repondents were used as the sample in this research. the answers of those respondents were submitted using questionnaire with multinominal logistic regression as the method used to process the data. this research use two independent variable which is financial management variable and financial literacy variable and one dependent variable which is family welfare. the result of this research stated that financial management variable (X1) affect family welfare of muslimah teacher at Selong sub-district while financial literacy variable (X2) wasn't.
\end{abstract}

Keywords: Financial Management, Financial Literacy, Family Welfare

\section{A. Introduction}

\section{A.1. Background}

Based on Central Bureau of Statistics (2017), West Nusa Tenggara Province is one of the 10 provinces with the largest number of poor people with a percentage of $16.02 \%$, where one of the regencies in this province is East Lombok Regency. East Lombok Central Bureau of Statistics (2017) also states that the people of East Lombok Regency consist of various types of professions or jobs, one of which is a teacher. The number of teachers in East Lombok Regency reaches 25,950 people (Central Bureau of Statistics, 2017).

For the teaching profession, when viewed from the current income it can be said to be better than a few years before, at least there are currently three sources of income received by teachers every month. First is salary, second is professional allowance and third is regional allowance. Even so the welfare felt by teachers has not been evenly distributed (Praditya, 2017). This is usually caused by lifestyle and lack of application of financial management or income by teachers, so that whatever income is received will always be lacking. The cause of family financial problems is due to weak management or financial management in the household itself.

Allah Subhanahu Wa Ta'ala has warned His servants to avoid being wasteful or excessive and squander the wealth as in the QS. Al-Isra' verses 26-27 Allah said: 
And give the relative his right, and [also] the poor and the traveler, and do not spend wastefully.Indeed, the wasteful are brothers of the devils, and ever has Satan been to his Lord ungrateful. (QS. Al-Isra':26-27).

To avoid wasting wealth extravagantly, financial management and planning is a must for every individual and family. Financial intelligence is absolutely necessary for every individual to continue to enjoy prosperity.

Based on the results of the National Financial Literacy and Inclusion Survey conducted by the Financial Services Authority (OJK) in 2016, it showed that the financial literacy index of West Nusa Tenggara Province was the second lowest after West Papua Province. Based on that financial literacy in West Nusa Tenggara Province can be said to be relatively low (Financial Services Authority, 2016).

The Financial Services Authority (2017), states that financial literacy can support efforts to achieve financial system stability and public welfare.

\section{A.2. Problem Statement}

This research consists of three problem formulations, namely:

1. Does financial management affect family welfare of Muslimah who work as teachers in Selong District?

2. Does financial literacy affect family welfare of Muslimah who work as teachers in Selong District?

3. How does the financial management and literacy influence on family welfare of Muslimah work as teachers in Selong District?

\section{A.3. Research Purposes}

This study aims to answer the questions contained in the formulation of the problem, the research objectives in this study are:

1. To determine the effect of financial management on the level of welfare of Muslimah family of teachers in the Selong District.

2. To determine the effect of financial literacy on the level of welfare of Muslimah family of teachers in the District of Selong.

3. Determine the effect of financial management and literacy on the level of welfare of Muslimah family of teachers in the Selong District.

\section{A.4. Research Limits}

The limitation of the study was carried out so that this research focused on the problems that were formulated, so that the discussion became narrow and not broad. In this study the authors limit the problem of how to manage finances and knowledge about finances for teachers in Selong District. The research area was conducted in Selong District, East Lombok Regency. The results of this study are expected to provide knowledge for respondents in order to manage finances well.

\section{B. Literature Review}

\section{B.1. Financial Management}


In the Indonesia Dictionary, financial management is a way to control or manage finances (kbbi.web.id, n.d.).

According to Sobaya et al. (2016), Financial management or planning is a process carried out by a person or individual to meet his financial goals, from a good plan will produce a clear financial plan.

Based on Bank Indonesia (2014), financial management is an action to achieve financial goals in the future. Financial management includes personal financial management, family financial management and corporate financial management.

\section{B.2. Financial Literacy}

Laily (2013), defines that financial literacy is one's knowledge and ability in managing finances. Financial literacy is the expertise and ability of people to use existing resources to achieve goals (Krishna et al. 2010).

Meanwhile, according to the Financial Services Authority (2017), knowledge of financial management or financial literacy is not limited to the understanding of knowledge, skills and beliefs about financial institutions, products and services, but wise attitudes and behaviors in determining financial goals.

\section{B.3. Family Welfare}

Based on Law Number 10 of 1992, a prosperous family is a family formed based on a legal marriage, able to meet the needs of a decent spiritual and material life, devoted to God Almighty, have a harmonious, conformable and balanced relationship between family members and between family with the community and the environment.

Welfare according to Anshori and Asjhari (2015), is a condition of meeting basic needs or basic needs based on the resources they have and the availability of access to various forms of socioeconomic services. In principle, aspects that can be observed in analyzing welfare include the dimensions of income, expenditure for consumption, employment status, health conditions, as well as the ability to access and utilize basic needs.

\section{B.4. Previous Research}

Research results from Muflikhati et al. (2010), stated that socioeconomic conditions that had a significant effect on family welfare in coastal areas differ according to the indicators used.

In a study conducted by Salleh (2013), it stated that the level of financial literacy was very significantly influential to the recipients of welfare assistance.

Research Results Ndakularak et al. (2014), stated that household expenditure for food and education had a significant effect on the welfare of the regency or city community in the Province of Bali and household expenditure for health did not affect the welfare of the regency or city community in the province of Bali.

\section{Research Method}

This research was conducted in one of the Districts in East Lombok Regency, 
Selong District. The population in this study were all Muslimah teachers in Selong District. Sampling was carried out using the issac table with a population of 586 and a significance level of $5 \%$, so the sample needed was 221 respondents, and the data used in this study were primary data obtained from distributing questionnaires to respondents. The scale used to measure financial management and literacy was a Likert scale with strongly disagree (score 1) and strongly agree (score 4). While the measurement for the level of family welfare used a nominal scale with 0 (no) and 1 (yes). To determine the effect of management variables and financial literacy on family welfare of Muslimah teachers in the District of Selong, Multinomial logistic regression analysis equation is used as follows:

Information:

$$
Y=\beta_{1} X_{1}+\beta_{2} X_{2}+\ldots . \beta_{j p} X_{p}
$$

Y $\quad=$ Dependent variable

$\beta_{\mathrm{jp}} \quad=$ Parameter

$\mathrm{X}_{1} \quad=$ Financial Management Variables

$\mathrm{X}_{2} \quad=$ Financial Literacy Variable

\section{C.1. Research Framework}

The framework of thought aims to explain all the variables to be studied and also to facilitate the operational formulation. All variables are arranged in a framework that shows the pattern of relationships as follows:

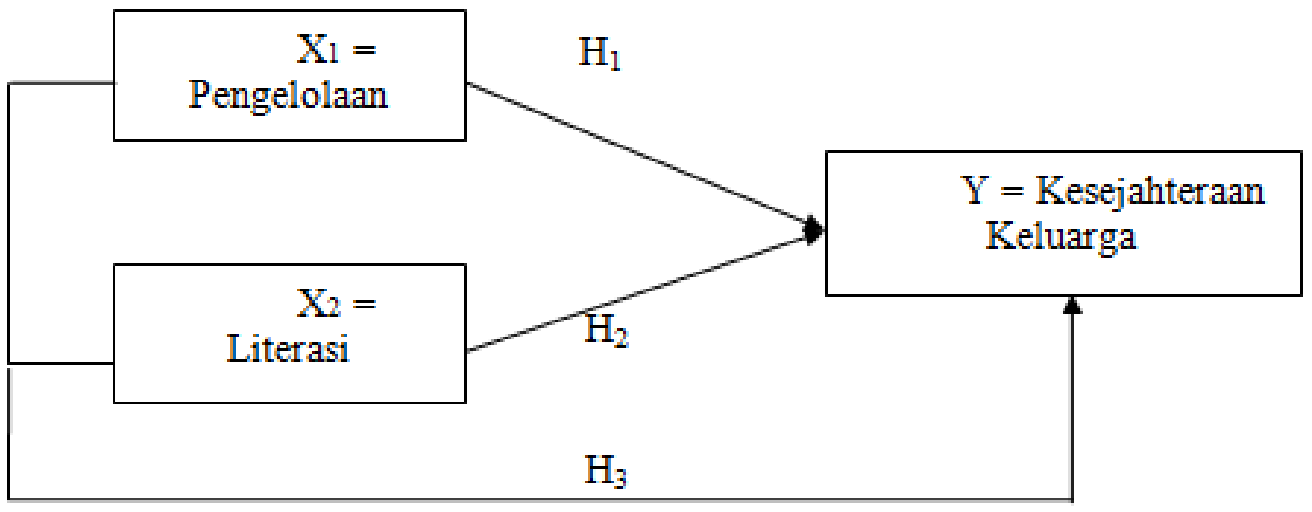

Figure 1. Research Framework

\section{C.2. Research Hypothesis}

The hypothesis for the problem of the management and financial literacy influence on the level of family welfare are:

H1: There is an influence between family financial management and family welfare. $\mathrm{H} 2$ : There is an influence between the level of financial literacy with family welfare. H3: There is an influence between management and literacy on family welfare. 


\section{Results And Discussion}

\section{D.1. Result}

In this study the number of respondents who filled out the questionnaire were 221 respondents with various demographics as follows:s

\begin{tabular}{|c|c|c|c|}
\hline \multicolumn{2}{|c|}{ Characteristics of Respondents } & Frequency & Percent \\
\hline Age & $\begin{array}{l}\text { 20-30 years old } \\
30-40 \text { years old } \\
40-50 \text { years old } \\
>50 \text { years old }\end{array}$ & $\begin{array}{l}39 \\
48 \\
45 \\
89\end{array}$ & $\begin{array}{l}18 \% \\
22 \% \\
20 \% \\
40 \%\end{array}$ \\
\hline Education & $\begin{array}{c}\text { Associate's Degree (D3) } \\
\text { Bachelor Degree (S1) } \\
\text { Master Degree (S2) } \\
\text { Doctorate Degree (S3) }\end{array}$ & $\begin{array}{c}13 \\
202 \\
6 \\
0\end{array}$ & $\begin{array}{c}6 \% \\
91 \% \\
3 \% \\
0\end{array}$ \\
\hline Group & $\begin{array}{c}\text { Civil Servants } \\
\text { Non Civil Servants }\end{array}$ & $\begin{array}{c}146 \\
75\end{array}$ & $\begin{array}{l}66 \% \\
34 \%\end{array}$ \\
\hline Husband's Work & $\begin{array}{c}\text { Civil Servants } \\
\text { Private } \\
\text { Entrepreneur } \\
\text { Does not work }\end{array}$ & $\begin{array}{l}98 \\
76 \\
34 \\
13\end{array}$ & $\begin{array}{c}44 \% \\
34 \% \\
16 \% \\
6 \%\end{array}$ \\
\hline $\begin{array}{c}\text { Number of } \\
\text { family members }\end{array}$ & $\begin{array}{l}2 \text { persons } \\
3 \text { persons } \\
4 \text { persons } \\
>4 \text { persons }\end{array}$ & $\begin{array}{l}42 \\
43 \\
75 \\
61\end{array}$ & $\begin{array}{l}19 \% \\
19 \% \\
34 \% \\
28 \%\end{array}$ \\
\hline $\begin{array}{c}\text { Wife Income Per } \\
\text { Month }\end{array}$ & $\begin{array}{c}<\operatorname{Rp} 1,000,000 \\
\operatorname{Rp} 1,000,000-\operatorname{Rp} 2,000,000 \\
\operatorname{Rp} 2,000,000-\operatorname{Rp} 3,000,000 \\
\operatorname{Rp} 3,000,000-\operatorname{Rp} 4,000,000 \\
>\operatorname{Rp} 4,000,000\end{array}$ & $\begin{array}{l}64 \\
11 \\
14 \\
47 \\
85\end{array}$ & $\begin{array}{c}29 \% \\
5 \% \\
6 \% \\
21 \% \\
39 \%\end{array}$ \\
\hline $\begin{array}{l}\text { Husband Income } \\
\text { Per Month }\end{array}$ & $\begin{array}{c}<\operatorname{Rp} 1,000,000 \\
\operatorname{Rp} 1,000,000-\operatorname{Rp} 2,000,000 \\
\operatorname{Rp} 2,000,000-\operatorname{Rp} 3,000,000\end{array}$ & $\begin{array}{l}35 \\
39 \\
60\end{array}$ & $\begin{array}{l}16 \% \\
18 \% \\
27 \%\end{array}$ \\
\hline
\end{tabular}




\begin{tabular}{|c|c|c|c|}
\hline $\operatorname{Rp} 3,000,000-\operatorname{Rp} 4,000,000$ & 53 & $24 \%$ \\
$>\operatorname{Rp} 4,000,000$ & 34 & $15 \%$ \\
\hline
\end{tabular}

The data in this study were tested using SPSS 25 software and produced the following statistical tests:

\section{a. Determination Coefficient Test}

Table 4.1 Determination Test

Pseudo R-Square

\begin{tabular}{|c|c|}
\hline $\begin{array}{c}\text { Cox and } \\
\text { Snell }\end{array}$ & .125 \\
\hline Nagelkerke & .180 \\
\hline McFadden & .112 \\
\hline
\end{tabular}

The table above gives the value of R2 as in the OLS regression which means the variation of the dependent variable that can be explained by all independent variables. Pseudo R-Square table will be used to see the ability of the independent variable in explaining the dependent variable, it can be seen in the Nagelkerke value column of 0.180 which shows that the ability of the independent variable in explaining the dependent variable is 0.180 or $18.0 \%$ and there are $100 \%-18 \%=82 \%$ other factors outside the model that explain the dependent variable.

\section{b. Partial Test}

Table 4.2 Partial Test

\section{Likelihood Ratio Tests}

\begin{tabular}{|l|l|l|l|l|}
\hline \multirow{2}{*}{ Effect } & $\begin{array}{c}\text { Model Fitting } \\
\text { Criteria }\end{array}$ & \multicolumn{2}{|l|}{ Likelihood } & \\
\cline { 2 - 6 } & $\begin{array}{c}\text {-2 Log Likelihood } \\
\text { ofReduced } \\
\text { Model }\end{array}$ & & & \\
& & Chi-square & df & Sig. \\
\hline Intercept & 190.707 & 12.045 & 3 & .007 \\
Pengelolaan & 204.234 & 25.572 & 3 & .000 \\
Literasi & 181.841 & 3.179 & 3 & .365 \\
\hline
\end{tabular}

The chi-square statistic is the difference in -2 log-likelihoods between the final model and a reduced model. The reduced model is formed by omitting an effect from the final model. The null hypothesis is that all parameters of that effect 
are 0 .

The Likelihood ratio test table above shows the contribution of each independent variable to the model. Variables that contribute to the model are management variables that have a significant value of 0.000 or $(p<0.05)$. While the financial literacy variable does not contribute to the model because of the significant value of 0.365 or $(p>0.05)$.

\section{c. Simultaneous Test}

Table 4.3 Simultaneous Test

\section{ModelFitting Information}

\begin{tabular}{|c|c|c|c|c|}
\hline \multirow{2}{*}{ Model } & \multirow{2}{*}{$\begin{array}{l}\text { Model Fitting } \\
\text { Criteria } \\
-2 \text { Log } \\
\text { Likelihood }\end{array}$} & \multicolumn{3}{|c|}{ Likelihood Ratio Tests } \\
\hline & & Chi-Square & $\mathrm{df}$ & Sig. \\
\hline Intecept Only & 208.197 & & & \\
\hline Final & 178.662 & 29.534 & 6 & .000 \\
\hline
\end{tabular}

The table above shows whether entering an independent variable into the model is better than a model that only includes intercepts. -2 log likehood only with intercept 208,197, while by entering independent variables, 2 log likehood dropped to 178,662 or Chi-square decreased by 29,534 and significant at $p=0.000$. So the model with independent variables gives better accuracy to know the level of welfare.

\section{d. Model Feasibility Test}

Table 4.4 Model Feasibility Test

\section{Goodness-of-Fit}

\begin{tabular}{|l|c|c|c|}
\hline \multicolumn{2}{|l|}{ Chi-Square } & Df & sig \\
\hline Pearson & 190.653 & 321 & .706 \\
\hline Deviance & 151.586 & 321 & 1.000 \\
\hline
\end{tabular}

The Goodness-of-Fit table provides information on whether the model used is compatible with data. In this table the Chi-square value is expected to be small, resulting in insignificant probabilities ( $p>0.05)$. A good model is a model that cannot reject the null hypothesis, ie the model fits or matches empirical data.

e. Equation Test

Table 4.5 Equation Test

Parameter Estimates 


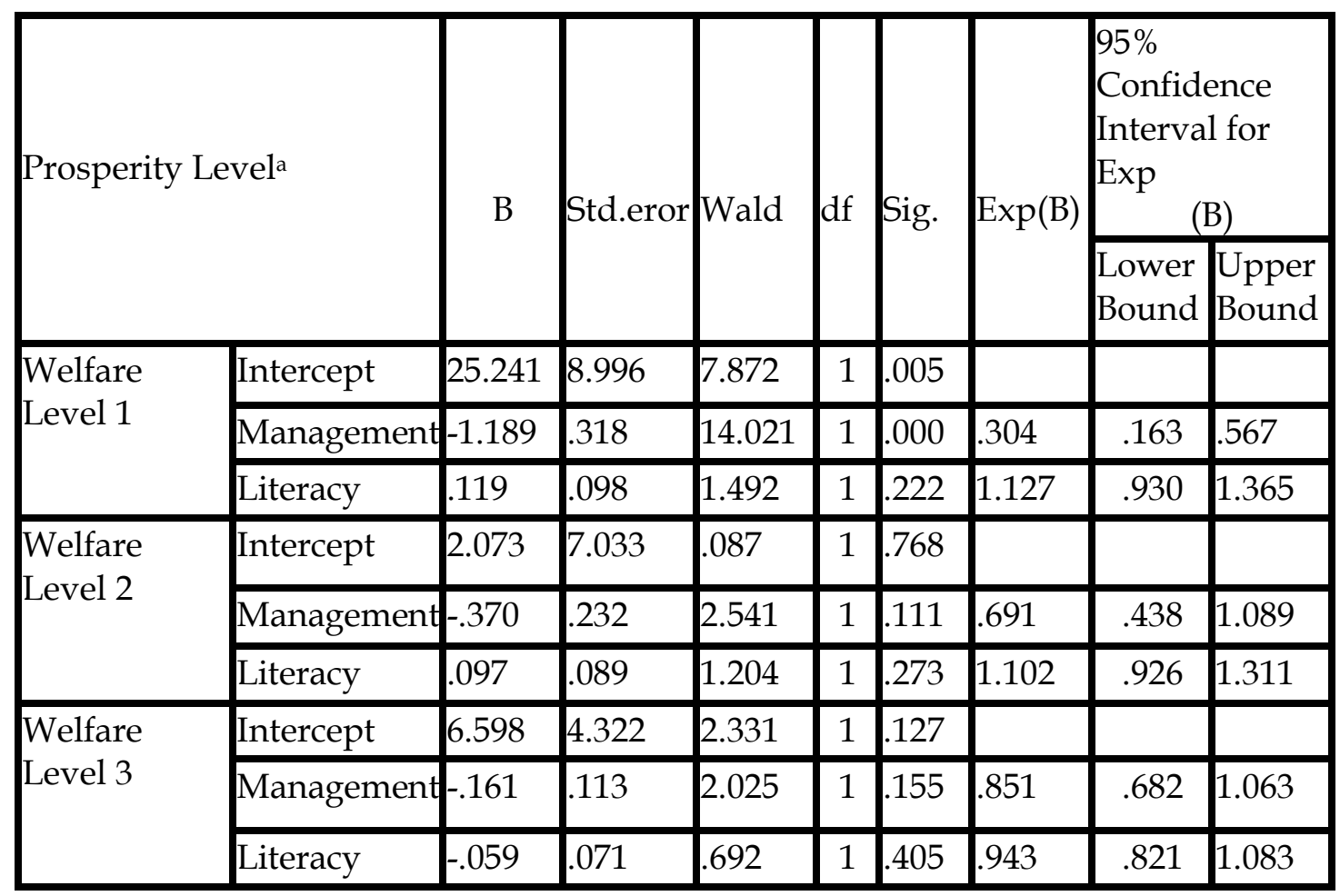

The reference category is: Welfare Level 3 Plus.

From the table above we get the equation as follows:

$$
\mathrm{Y}=25,241-1,189 \text { (Management) }+0.119 \text { (Literacy) }
$$

1. Financial management variables (X1) significantly influence the welfare of firstlevel families with a coefficient of -1.189 and a significant value of 0.000 or $p$ $<$ alpha (0.05) with an odd ratio value of 0.304 . This means that there is a relationship between the way financial management is carried out by Muslimah teachers in the District of Selong to the level of family welfare based on the level of family welfare according to the Indonesian Population and Family Information Network (BKKBN).

2. Financial literacy variable $(\mathrm{X} 2)$ does not significantly influence the welfare of first-level families with a coefficient value of 0.119 and a significant value of 0.222 or $p>$ alpha $(0.222)$ with an odd ratio value of 1.127 . This means that there is no relationship between financial literacy owned by Muslim women who are teachers in the District of Selong on first-level family welfare based on welfare according to the BKKBN.

$$
\mathrm{Y}=2.037-0.370 \text { (Pengelolaan) }+0.097 \text { (Literasi) }
$$

1. The financial management variable (X1) does not significantly influence the welfare of second-level families with a coefficient value of -0.370 and a significant value of 0.111 or $p>$ alpha (0.05) with an odd ratio value of 0.691 . This means that there is no relationship between financial management owned by Muslim women who work as teachers in Selong District on the welfare of second-level families, based on the level of welfare according to theIndonesian 
Population and Family Information Network(BKKBN).

2. Financial literacy variable (X2) has no significant effect on the welfare of seconddegree families with a coefficient of -0.097 and a significant value of 0.273 or $p>$ alpha (0.05) with an odds ratio of 1.102. This means that there is no relationship between financial literacy owned by Muslim women who are teachers in the District of Selong to the welfare of second-degree families based on welfare according to the BKKBN.

$$
\mathrm{Y}=6.598-0.161 \text { (Pengelolaan) }-0.059 \text { (Literasi) }
$$

1. Financial management variable (X1) has no significant effect on the welfare of third-level families with a coefficient value of -0.161 and a significant value of 0.155 or $\mathrm{p}>$ alpha $(0.05)$ with an odds ratio of 0.851 . This means that there is no relationship between the financial management owned by Muslim women who work as teachers in Selong District on the level of third-level family welfare based on the level of welfare according to the Indonesian Population and Family Information Network (BKKBN).

2. Financial literacy variable $(\mathrm{X} 2)$ does not significantly influence the welfare of third-level families with a coefficient value of -0.059 and a significant value of 0.405 or $\mathrm{p}>$ alpha (0.05) with an odd ratio value of 0.943 . This means that there is no relationship between financial literacy owned by Muslim women who work as teachers in Selong District on the level of third-level family welfare based on the level of family welfare according to the BKKBN.

\section{D.2. Discussion}

\section{D.2.1 The Effect of Financial Management on Family Welfare of Muslimah Teachers with Teacher Professions in Selong District}

The first hypothesis in this study is that financial management affects family welfare. Based on the results of the multinomial logistic regression test, it shows that financial management has a significant effect on the welfare of Muslimah family members who are teachers in Selong District. This financial management variable has a significant value of 0.000 or $(p<0.05)$ so that it can show that the management variable has a significant effect on the welfare of the family of Muslimah teachers who are teachers in the District of Selong. Based on these results, this study succeeded in proving the hypothesis that states "financial management affects family welfare". Judging from the index of respondents 'answers based on financial management variables also showed that the average value of the respondents' answers index was 3.20 which was included in the high category. From the results of the answer index, the majority of respondents made a budget and felt the effects of budgeting, as seen in the very high answer index values contained in questions one, two, four and six. The majority of respondents are also concerned about the cost of children's education. In addition, the majority of respondents also realized the importance of setting aside emergency funds.

The results of this study are supported by research conducted by Fajrin (2011) which stated that family financial management had a positive relationship on subjective well-being of the family. 


\section{D.2.2 The Effect of Financial Literacy on Family Welfare of Muslimah Teachers with Teacher Professions in Selong District}

The results of this study also show that financial literacy has no significant effect on the welfare of Muslimah family members who are teachers in Selong District. This is evidenced by the results of the statistical test on the partial test which states that the financial literacy variable does not contribute or does not affect the welfare of the family with a significance value of 0.365 or $(p>0.05)$, then this study cannot prove the hypothesis stating "financial literacy is influential towards family welfare ", so hypothesis two (H2) is rejected.

In the index results of the answers to the literacy of the majority of respondents can be said to have good literacy, however, if viewed from the level of literacy, a Muslimah who is a teacher in the District of Selong belongs to the less literate group, where the less literate class is the respondents who only have knowledge of financial service institutions, products and services but do not believe and do not have the skills to use them.

\section{D.2.3. The Effect of Financial Management and Literacy on Family Welfare of Muslimah Teachers with Teacher Professions in Selong District}

The results of this study indicate that financial management and literacy affect the level of family welfare based on the BKKBN. This can be proven based on the results of the simultaneous test by looking at the final value in the fitting information model table. The final value in the fitting information model shows a significance of 0.000 or $(p<0.05)$ so that based on these results it can be concluded that the variable management and financial literacy both affect the welfare.

In addition to using management variables and financial literacy, family welfare can also be influenced by several other factors such as the number of family members, family income, education level, asset ownership, occupation of the head of the family and expenditure allocation (Widyaningsih \& Muflikhati, 2015).

\section{E. Conclussion and Suggestions}

\section{E.1. Conclussion}

Based on the results of research on the Analysis of the Effects of Financial Management and Literacy on Family Welfare Levels by conducting a case study on Muslimah teachers in Selong District as discussed in chapter 4, the following conclusions will be drawn:

1. The results showed that the Financial Management variable had a positive and significant effect, the results showed that financial management which included making household budgets, monthly expenditures and evaluations had an influence on the level of welfare of Muslimah family members who were teachers in the Selong District. The first hypothesis in this study is that there is an influence between financial management on family welfare. Based on the discussion in chapter 4, it can be concluded that hypothesis one (H1) is accepted or in other words the management has an influence on the welfare of Muslimah 
families with teacher profession in Selong District.

2. For Financial Literacy variable does not affect the welfare of the family of Muslimah family of teachers in the District Selong. This is because the results of the study in chapter 4 show that financial literacy is not significant, indicated by the significance value of 0.365 , which is greater than alpha (0.05). The second hypothesis contained in this study is that there is an influence between financial literacy on family welfare of Muslimah teachers in the District of Selong, based on this the authors conclude that $\mathrm{H} 2$ is rejected or in other words financial literacy does not have an effect on the welfare of Muslimah family of teachers in the profession Selong District.

3. Based on the results of the simultaneous test shows that the variable Management and Financial Literacy has a significant effect on the welfare of Muslimah family of teachers in the Selong District. This can be seen from the test results obtained Chi-Square probability value generated 0.000 , where the value is smaller than alpha (0.05).

\section{E.2. Suggestions}

After seeing the results and conclusions from the research that the author has done, the suggestions from the author are as follows:

1. For the next researcher

For further research, new variables or new indicators can be added and then use subjective well-being variables as the dependent variable and use different analyzes in order to provide a broader analysis, so as to improve the results of the study. Then test the financial literacy variables one by one on each indicator.

2. For Muslimah who work as teachers in the District Selong In this study financial management variables affect family welfare of Muslimah teachers in Selong District. With this influence it is recommended that Muslimah teachers pay more attention and improve family financial management.

\section{Bibliography}

Anshori, A. N., \& Asjhari, A. (2015). Relationship of Financial Literacy and Public Welfare Changes After Land Compensation for Toll Road Development in Bongaswetan Village Majalengka. Jurnal Sosek Pekerjaan Umum, 7, 1-79.

Badan Pusat Statistik Lombok Timur. (2017). Kabupaten-Lombok-Timur-DalamAngka-2017. Selong. Retrieved from http://lomboktimurkab.bps.go.id

Bank Indonesia. (2014). Pengelolaan Keuangan. Departemen Pengembangan Akses

Keuangan dan UMKM Bank Indonesia. Retrieved from http://www.bi.go.id/id/perbankan/keuanganinklusif/edukasi/Contents/ Pengelolaan Keuangan Modul Pelatihan.pdf

kbbi.web.id. (n.d.). Pengelolaan menurut KBBI. Retrieved from https://kbbi.web.id/kelola

Krishna, A., Rofaida, R., \& Sari, M. (2010). Analisis Tingkat Literasi Keuangan(Survey pada Mahasiswa Universitas Pendidikan Indonesia), (November), 552-560. 
Laily, N. (2013). Pengaruh Literasi Keuangan Terhadap Perilaku Mahasiswa Dalam Mengelola Keuangan. Journal of Accounting and Business Education, 1(2013: Jurnal Pendidikan Akuntansi (JPA): Vol. 1, No. 4, September 2013). Retrieved from http://journal.um.ac.id/index.php/jabe/article/view/6042

Muflikhati, I., Hartoyo, Sumarwan, U., Fahrudin, A., \& Puspitawati, H. (2010). Socio-economic Factors and Family Welfare: The Case of Coastal Area in West Java. Jurnal Ilmuu Keluarga Dan Kunsumen, 3(1), 1-10. Retrieved from http://ikk.fema.ipb.ac.id/v2/images/jikk/v3n1/1.pdf

Ndakularak, E., Setiawina, N. D., \& Djayastra, I. K. (2014). Analisis Faktor-Faktor yang Mempengaruhi Kesejahteraan Masyarakat Kabupaten/Kota di Provinsi Bali. E-Jurnal Ekonomi Dan Bisnis Universitas Udayana, 14.

Otoritas Jasa Keuangan. (2016). Survei Nasional Literasi Dan Inklusi Keuangan 2016. Retrieved from www.ojk.go.id

Otoritas Jasa Keuangan. (2017). Strategi Nasional Literasi Keuangan Indonesia ( Revisit 2017). Jakarta.

Praditya, I. stianur. (2017). Tunjangan Meningkat. Retrieved from http:/ / m.liputan6.com/bisnis/read/3175063/tunjangan-meningkat-berapapenghasilan-guru-saat-ini

Salleh, A. M. H. A. P. M. (2013). A comparison on financial literacy between welfare recipients and non-welfare recipients in Brunei. International Jurnal of Social Econimic, 42(7, p.598-613,). https://doi.org/10.1108/IJSE-09-20130210

Sobaya, S., Hidayanto, M. F., \& Safitri, J. (2016). Pengaruh Literasi Keuangan Dan Lingkungan Sosial Terhadap Perencanaan Kauangan Pegawai, 20. https:// doi.org/10.7910/mdn.v20i1.90

Undang-Undang Republik Indonesia Nomor 10 Tahun 1992. (1992). UndangUndang Republik Indonesia Nomor 10 Tahun 1992 Tentang Perkembangan Kependudukan Dan Pembangunan Keluarga Sejahtera. Undang-Undang142. Retrieved from https://peraturan.bpk.go.id/Home/Details/46602

Widyaningsih, E., \& Muflikhati, I. (2015). Alokasi Pengeluaran DanKesejahteraan Keluarga Pada Keluarga Nelayan Bagan. Jurnal Ilmu Keluarga Dan Konsumen, 8(3),182-192. 